\title{
Utilization of Advanced Technologies for in-situ Remediation of Polluted Soil to avoid Ecological Risks: A Review
}

\author{
Aparna Pandey, Pratibha Singh, Divya Gupta, Abreeq Fatima, \\ Sheo Mohan Prasad ${ }^{*},{ }^{*}$
}

Soil pollution cannot be directly assessed or visually perceived generally and has become a hidden danger. It is mainly contributed by contamination from chemicals, heavy metals, pesticides, polycyclic aromatic hydrocarbons, and persistent organic pollutants. Soil pollutants are antagonistic to diversified life forms on earth ranging from soil microbes, plants, and mankind to water inhabitants and aerial lives, food security, agricultural productivity thereby exerting detrimental effects and so need immediate attention. The remediation of contaminated soil is necessary for sustainable development and continual existence of life forms on the planet. Ecological remediation depends chiefly on utilizing different innovations like adsorption, assimilation, compound responses, photo-catalysis, and filtration for the expulsion of contaminants from natural media like soil. This review elucidates various soil pollutants from natural to manmade sources and its affect on the environmental components. It further aims to look at recent advances in various remediation technologies for removing contaminants from soil. Besides the traditional methods of remediation, techniques involving biological methods, biotechnological approach and nanotechnology have been focused. Some possible opportunities and challenges of varying soil remediation strategies are discussed. It would suggest new perspectives and future challenges in soil remediation.

\section{Introduction}

Soil is one of the important constituents of the ecosystem similar to water, air, plants and animals, developed by natural forces which is further differentiated into horizons of minerals and organic constituents [1]. Its composition are several dynamics like organic matter, minerals, liquids, gases and organisms and thus acts as a natural resource supporting life. It impacts air, water, human as well as animal health by acting as an interface between biosphere, atmosphere and hydrosphere [2]. Occurrence of complex processes such as plant-pathogen interactions, apart from abiotic constituents, form it heterogeneous [3]. Nevertheless, soil provides medium for the growth of the plants, in storage, supply and sanitization of water, transformer of earth's atmosphere, and habitat for organisms which make it a critically important tool of ecosystem services [4].

Ranjan Plant Physiology and Biochemistry Laboratory,

Department of Botany, University of Allahabad, Prayagraj, India

The authors Aparna Pandey and Pratibha Singh contributed

equally to the review.

${ }^{*}$ Corresponding author:

E-mail: profsmprasad@gmail.com; Tel.: 9450609911

DOI: $10.5185 / \mathrm{aml} .2021 .15698$

It harbours various organisms and holds tremendous range of niches and habitat. Prokaryotic density of soil is mean of approximately $10^{8}$ organisms per gram [5]. Soil offers plants protection from poisons, moderates air, water, temperature and nutrients, by transforming dead organic matter into several form of nutrients. And by commendably eliminating impurities, destroying disease agents [6] and vitiate contaminants, acts as a natural attenuator.

\section{Soil pollution}

Soil traps various harmful pollutants that leach through various activities. Soil is regarded as universal sink for all kinds of wastes of the society [7]. Wars, release of radionuclides through atmospheric weapons, mining, industrialization, oil spills, urban sprawl, unsustainable agricultural practices acted as source of pollution to the soil through the past decades $[\mathbf{2 , 8}]$. Though soil acts as a buffer yet its ability to mitigate pollutants is limited thus exceed in amount of contaminants causes soil pollution [9]. It is also defined as the reduction in the productivity of soil [10]. Presence of harmful substances in the soil cause damage to non-target organisms [11]. In 1957, the United States Department of Agriculture reported soil pollution to be the source of toxicity to human diet. 


\section{Advanced Materials Letters https://aml.iaamonline.org}

\section{Soil pollutants and contaminants in present scenario}

Industrial revolution began in the early eighteenth century which was rampant during mid-nineteenth century [12]. Increasing industrialization resulted addition of unwanted pollutants directly as well as indirectly. Industries are dependent on minerals extracted from the earth as raw materials and fuel purposes, whereas iron, coal etc. which remain further contaminate it. Industrial activities lead to accumulation of heavy metals such as $\mathrm{Pb}, \mathrm{Hg}, \mathrm{Cr}$, As and also radioactive heavy metals such as $\mathrm{U}, \mathrm{Ra}, \mathrm{Pu}$. Soil pollution is contributed both by pollutants and contaminants. Soil pollutants include two main groups viz., the organic pollutants (OPs) and the inorganic pollutants (IPs). OPs are toxic as are persistent, soluble (in water or organic solvents) resulting in accumulation of by-products from their (bio) degradation. Industries emit harmful gases, particulate matter and untreated effluents which get deposited at wide areas. Inorganic components of industrial wastes are harmful to soil. Potentially toxic elements (PTEs) are considered priority pollutants, since they are nondegradable and persistent in the environment for longer periods [13]. Factories and thermal plants emit $\mathrm{SO}_{2}$ which make soil acidic [14]. Further, dumping of industrial wastes on land, about one fourth of which remains undegraded each year is a major cause behind soil pollution. The spread of radioactivity, harmful materials through wind is a matter of great concern via settling down from the atmosphere and radionuclides pollute the soil to such an extent that it loses the fertility to support good crop production [15].

Metals being non-biodegradable, remain persistent in the soil by undergoing complexation, absorption and dissolution [16]. Major sources of heavy metals contamination are the industrial effluents. Arsenic (As) contaminates soil which comes through volcanic eruptions [17]. Natural causes of heavy metals contamination are related to igneous rocks that lead to high concentrations of $\mathrm{Cr}$ in soils from Croatia (Pannonian Region), higher $\mathrm{Pb}$ levels found in rock-forming alumosilicates and in K-rich igneous rocks and pegmatite [18]. Weathering of As containing minerals and ores are also a major cause for environmental problem [7]. Major sources of heavy metal pollution in the soil are discharge of industrial effluents which contaminate water bodies and ultimately agricultural fields when irrigated by it and can enter the food chain. Due to addition of industrial effluents, an increased amount of $\mathrm{Na}^{+}, \mathrm{Cl}^{-}, \mathrm{SO}_{4}{ }^{2-}, \mathrm{As}, \mathrm{Ni}, \mathrm{Pb}, \mathrm{Zn}, \mathrm{Cr}, \mathrm{Fe}, \mathrm{Cd}, \mathrm{Co}, \mathrm{Sn}, \mathrm{Cu}$ have contaminated crop lands [19]. Application of pesticides associated with heavy metals like $\mathrm{Cu}, \mathrm{Hg}$ also intensify the pollution in soil [14].

The world's waste water referred to as sewage is nowadays applied in agricultural farms in developed countries of North America, Europe, and countries like Belgium, Spain, Denmark, Ireland, France, and United Kingdom [20, 21] also in developing countries like India [22]. Concerns are now raised on use of sewage as organic manure on terrestrial land as its prolonged use might increase the risk of pollutants (like heavy metals viz., $\mathrm{Cd}$, $\mathrm{Cu}, \mathrm{Ni}, \mathrm{Pb}, \mathrm{Zn}, \mathrm{Hg}, \mathrm{Cr}$ etc.) and pathogens to plants and crops.

Pesticides application constitute one of the essential practice of farmers to survive crops from diseases, pests, weeds etc. and meet food demand of rising population. Extensive use of pesticides pollutes soil, their residue persists in soil and affect $90 \%$ of non-target vegetation [23]. Pesticides leak into ground and contaminate soil, leave a permanent effect. Application of fertilizers to increase the nutrients contents ultimately decrease the soil fertility [10]. Organochlorines have been detected highest in the soil of Brazil [24]. Glyphosate with AMPA were highest in European agricultural fields because of the persistent behaviour [25]. Organophosphorous compounds, the most used insecticides, in the recent decades have developed resistance in many insects. Carbamate and pyrethroids insecticides are used against various kind of insects such as lepidopterous insects, Hemiptera, Diptera and Coleoptera [26]. Some pesticides associated with heavy metals like $\mathrm{Cu}$ based fungicides, $\mathrm{Cd}, \mathrm{Fe}, \mathrm{Mn}, \mathrm{Zn}, \mathrm{Pb}, \mathrm{Hg}$ and $\mathrm{Ni}$ have led to contamination of the soil [10]. Sharma et al., [27] advocated the use of bio-pesticides in place of chemical pesticides to reduce soil pollution.

Volcanic eruptions including lava, volcanic dust, ashes and gas compounds which destroy the landscapes and natural resources [28]. Volcanic eruptions of 50 to 60 occur each year and contribute to contamination of land [29]. Volcanic ash and mud when mix with rain or melting snow cause mudflows and acid rain [28]. Volcanic soil and ash mostly consist of metals like $\mathrm{Mn}, \mathrm{Cu}, \mathrm{Pb}, \mathrm{Zn}, \mathrm{Cr}, \mathrm{Ni}, \mathrm{Co}$ and As, of which $\mathrm{Cr}$ and As possess carcinogenic as well as non-carcinogenic risks [30]. Large areas of land, vegetation, water sources etc. get affected by them. Sulphur compounds and sulphur dioxide, released in the environment cause acid rain. As being acidic, $\mathrm{N}$ is a component of acid rain which contributes to nitrogen pollution that affects aquatic organisms, soil etc. [31]. Acid rain changes $\mathrm{pH}$, nutrients composition of soil as solubility of nutrients depends on the $\mathrm{pH}[32]$.

\section{Effects of soil pollution on major areas}

\section{Crop productivity}

Food production needs to be increased by $70 \%$ essentially by 2050 [33] but the increasing soil pollution alters the soil composition making it unsuitable for the growth of plants and beneficial microorganisms. With the upsurge in the human population, there is subside in available land area for cultivation, consequently, a decline in crop productivity which leads to the major threats for stable agricultural sustainability [34]. Major heavy metals such as $\mathrm{Ca}, \mathrm{Cd}$, $\mathrm{Cr}, \mathrm{Ni}, \mathrm{Pb}, \mathrm{Zn}$ and $\mathrm{Cu}$ contaminate vegetables when they are present at higher than the permissible limits. Singh et. al., [35] have reported that Cr caused toxicity in 


\section{Advanced Materials Letters https://aml.iaamonline.org}

S. lycopersicum and S. melongena seedlings, affected several biochemical and physiological parameters.

Soil pollution leads to emission of $\mathrm{N}$ in large quantities by denitrification and decomposition of organic materials in the soil [36] which affects crops growth. Nutrients present naturally in the soil are lost due to soil pollution and affect crop growth [10]. Soil polluted with $\mathrm{Pb}$, asbestos, and $\mathrm{S}$ is unfavourable for crop growth. Singh et. al., [37] reported that stress reduced growth of mustard seedlings was alleviated in presence of $\mathrm{Ca}$ and NO. Similarly, Bashri and Prasad [38] studied the effect of IAA (Indole Acetic Acid) in alleviation of Cd caused toxicity in Trigonella foenum-graecum L. seedlings. Acid rain leads to a continuous cycle of pollution by altering soil composition, reducing nutrients content which are important for crop growth. Acidity in soil leaches important minerals such as $\mathrm{Ca}$ and $\mathrm{Mg}$ and hinders the ability to maintain the soil $\mathrm{pH}$ causing plants death due to unfavourable conditions [39]. Moreover, acidic deposition into the soil can hamper its ability to buffer, this changes soil $\mathrm{pH}$, alters plant metabolism causing early deaths of plants and ultimately decreased crop productivity.

\section{Fertility of major land areas}

World population is expected to keep growing and reach 8.6 billion by mid-2030 thereby increasing food demand and hence urge for food security. Nutrient imbalance and soil acidification are consequences of soil pollution [40]. Reduced soil fertility directly impacts plant productivity [41]. Soil pollution makes the soil toxic, unhealthy for vegetation thus soil becomes useless and barren [10]. The use of chemical fertilizers in agricultural fields also caused decreased soil fertility. Poffenbarger $e t$. al., [42] studied the impact of $\mathrm{N}$ fertilization in maize fields at Midwest U.S. and found site-to-site variability on soil health and crop yield. The industrial discharge containing heavy metals (lead and arsenic) impacted plant's fertility [43].

\section{Health of soil microflora}

The functioning of the soil as a vital system supporting biological productivity depends to a higher extent on soil's microflora activity. The existence of substantial amount of different biologically active chemical substances (heavy metals, pesticides, polycyclic carbohydrates, furans, polychlorinated biphenyls, dioxins, and petroleum products etc.) affect the functioning of soil's fertility. Because of large persistence, pesticides used in agricultural fields not only kill pests but also useful microflora, posing a potential risk of harmful influence on the bio-ecosystems [10]. High use of chemicals leads to leachate into soil and killing of useful microflora which aid to plants' growth [44]. Soil microorganisms play essential role in decomposition of organic matter thus maintaining nutrient cycle [45] and also maintain soil structure for water retention and penetration [46]. Cr and As toxicity causes severe reduction in growth of paddy fields cyanobacteria N. muscorum and Anabaena sp. $[\mathbf{4 7 , 4 8}]$. Cypermethrin, a pyrethroid caused decline in growth on essential nitrogen fixing cyanobacterium by affecting the enzymatic and non-enzymatic antioxidants [49]. Chlorinated organic pesticides such as DDT, dieldrin, eldrin are present in the soil surface layers even after 30 years [50]. Dusek [51] have reported that increasing doses of polychlorinated biphenyls (PCPs) brought a strong decrease in the nitrite oxidizing bacteria. High concentrations of heavy metals can accumulate everlastingly in toxic doses and remain undegraded, especially $(\mathrm{Cd}, \mathrm{Pb}, \mathrm{As}, \mathrm{Cu}, \mathrm{Ni})$ thereby adversely affecting the size, diversity and activity of microbial populations in soil [52]. This very reason of pesticide determination to influence microflora of the polluted sites is very alarming and requires applications of remediation techniques. Recent studies report about application of organic soil inputs to diminish the negative effects of pesticides $[\mathbf{4 1 , 8 , 1 1 ]}$.

\section{Human health}

Plants grown in contaminated soil pass absorbed soil contaminants into food chain ultimately leading to bioaccumulation up to highest trophic level, thus impact human health [53]. Toxic chemicals enter the human system by direct route through the human contacts, indirectly via crops growing on them or through drinking water that accumulates leached chemicals from the polluted land $[\mathbf{5 4 , 5 5}]$. $70 \%$ of soil pollutants are carcinogenic and their exposure to humans leads to cancer. Long term effects of soil pollution have been seen to cause cancer, leukemia, reproductive disorders, kidney damage, central nervous system failure etc. [56]. Thalamates and Bisphenol A leach out of plastic particles and effect the hormone system of vertebrates and invertebrates. Nano-size particles are reported to cross selectively permeable membrane such as blood brain barrier and placenta [56]. Human illnesses such as migraines, nausea, miscarriages have been more reported in people living nearby polluted lands. Toxic gases and foul odours emitted from landfills also cause serious health effects in humans [10]. As because of troublesome microbiological analysis, soil pollutants dissolved water bodies are not examined for viruses, they pose a considerable threat to humans and animals $[\mathbf{5 7 , 5 8}]$.

Soil pollutants are harmful to brain development in children (loss of IQ) and lead to neurological disorders [59]. It is also reported that long term exposure to benzene and polychlorinated biphenyls (PCB) caused leukemia and liver cancer, respectively. High concentrations of lead and mercury damage liver and kidney $[\mathbf{6 0 , 6 1}]$. Another important group of inorganic contaminants are radionuclides which are unstable isotopes that may undergo radioactive decay (e.g., $\mathrm{Cs}, \mathrm{Sr}, \mathrm{Eu}$ and $\mathrm{Th}$ ). Therefore, they emit radiation which may be harmful [62]. Radioactive metals discharged through industrial wastes cause damage to chromosomes, lead to mutations, cancers in animals, and humans [63]. Several regulations have been implemented against industrial pollution to minimize soil pollution. 


\section{Advanced Materials Letters https://aml.iaamonline.org}

\section{Population of birds and other predators}

Soil pollution leads to less availability of food, habitat to birds by impacting the vegetation of area. The decline in forest due to slow leaching of heavy metals from contaminated soil is regarded one of major factor behind birds decline [64]. Metal pollution caused decline in $\mathrm{Ca}-$ rich insects such as snails consequently affected feeding habit of insectivorous birds, thus their population declined also because of requirement of $\mathrm{Ca}$ by breeding females [65]. It causes habitat loss of several herbivores in turn other animals that are dependent on them [66]. As soil pollution negatively affects vegetation thus causes migration of birds in search of food and shelter [67]. Toxins, pollutants, bacteria etc. have caused death of heaps of birds (29 species) at Sambhar lake, Union Environment Ministry found it the worst death in ecosystem [68]. A decade ago, DDT had been reported to pollute soil and cause decline in population of birds such as ospreys and brown pelicans by destroying their eggs, in 1970s most developed nations prohibited utilization of DDT. Effect of long-term pollution has been studied on breeding-bird's density, species diversity and biomass by Eeva et. al., [69] who reported smelters based on metals pose danger on local breeding bird populations. They reported, Russian copper smelters caused a $40 \%$ decline in bird densities in Reveda concluding, species diversity, species number also decreased near pollution source.

Mitra et. al., [70] reported, exposure to specific pesticides blocked singing capacity, making it hard to attract mates and reproduce in winged creatures. Pesticides likewise influence bird's capacity to care for their posterity causing their young ones to die. Effect of tiny levels of pesticides result in sublethal impacts, affecting versatility, taking care of feeding practices, and route in honey bees. Mnif et. al., [71] studied on the numerous deformations in wildlife found after introduction to hormone-mirroring pesticides delegated as endocrine disruptors. Effect of persistent harmful synthetic pollutants on the sea shores is seen in the food web which brought about an assortment of effects on wildlife around, their debilitated reproduction, reduced resistance from diseases, anemia, neurological harm, and birth weaknesses in offspring [72]. The effects of synthetic substances include androgynous deformations in frogs, pseudo-bisexual polar bears, panthers with decayed testicles, and intersex fish in waterways. Mitra et. al., [70] found that aimless utilization of engineered synthetic chemicals caused decrease of raptorial birds' population across the world because of DDT like the peregrine bird of prey, the sparrow sell, and bald eagle.

Plastic pollution is an alarming issue worldwide due to rapidly increased plastic products. Plastic pollution is leading to death of 1 million sea-birds every year [73]. State of World's birds 2018 have reported that 1 out of 8 birds ( $13 \%$ of existing species) have become prey of plastic as its small particles resemble food and akes hundreds of years to break it [74]. Millions of animals are killed by plastic every year from land-based animals such as cattle, camels, zebra, elephants, hyenas, tigers and other large mammals to turtles, seals, whales [75].

\section{Soil pollution remediation technologies during current scenario}

Remediation of polluted soil is the need of the hour, since a large area is under constant pressure of getting polluted by enormous contaminants whether coming from industries of fertilizer or tanneries or leather etc. No single technique is sufficient for eradication of soil pollutants. New technologies are still being adopted in form of biotechnology or nanotechnology besides the traditional ways of soil remediation.

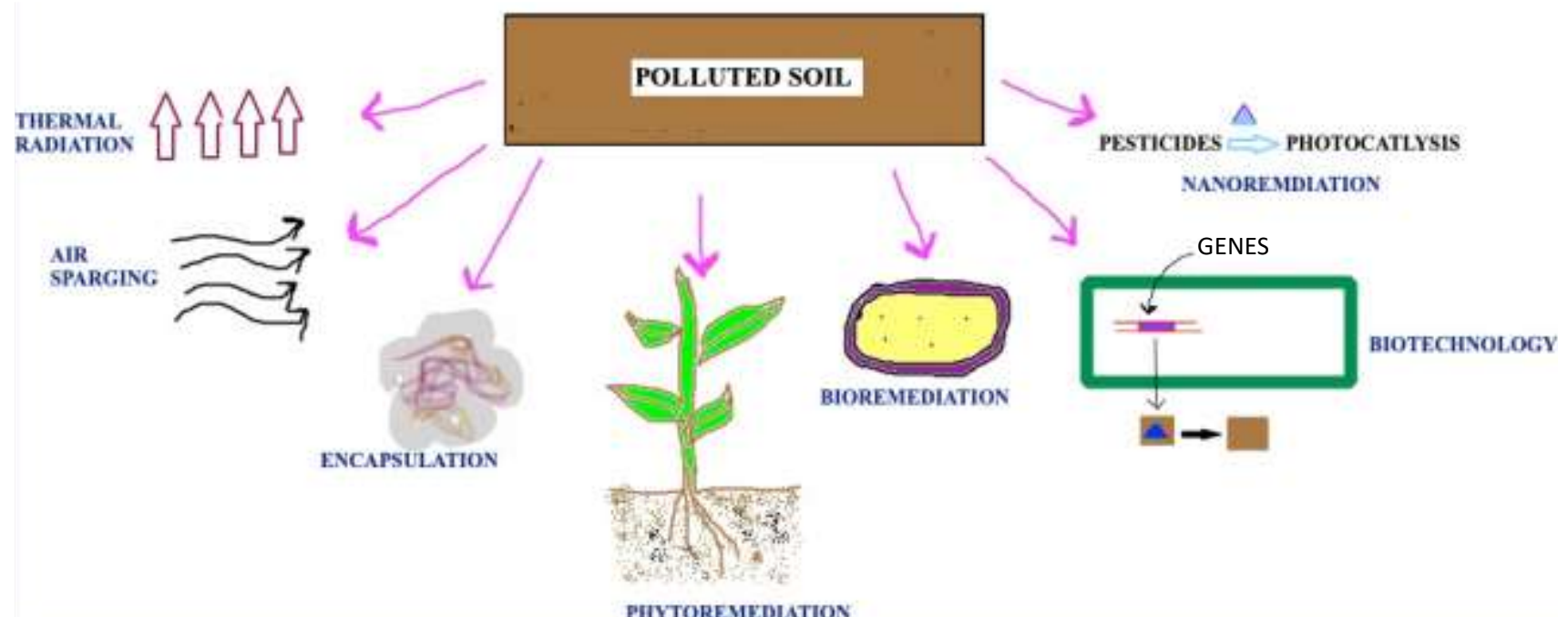

Fig. 1. Various soil remediation strategies. 


\section{Advanced Materials Letters https://aml.iaamonline.org}

\section{Thermal soil remediation}

Thermal soil remediation was used to eliminate the contamination from a former site of distribution center of new and second-hand cars operating since 1970. The site was contaminated with wax layer from new cars, solvents, mixture of $1.5 \%$ of petroleum and water. The contamination was found to be reduced upto $50 \%$ by the use of thermal process. "In-situ" remediation target the source of pollution, engineered nano-materials (ENMs) facilitate thermal in-situ remediation of chlorinated VOCs. [76]. This process includes heating of contaminated soil into the primary treatment unit (PTU) to evaporate the impurities (hydrocarbons) and water [77] (Fig. 1). These contaminated materials are kept at the temperatures of $650{ }^{\circ} \mathrm{F}$ to $900{ }^{\circ} \mathrm{F}$ and are delivered from the PTU into a cooling unit, which is an auger wherein the water is added for cooling and dust control. At last, the treated material is discharged from the cooling unit which is now ready for testing and further recycling [78].

\section{Air sparging}

In this technique, large volumes of air are injected into a polluted soil which forces the organic pollutant outwards in the form of vapour where the vapour is treated by carbon filtering [79] (Fig. 1). The time of the treatment varies from factor to factor including depth of the hydrocarbon pollution, degree of contamination, $\mathrm{pH}$ and permeability of the soil $[\mathbf{8 0}]$.

This remediation was started in October 1988 due to leakage of estimated 2 million gallons of gasoline, fuel oil, and kerosene in 1987 at Amoco Corporation operating liquid petroleum product pipeline along Constantine site by groundwater pump treat system consisting of 4 extraction wells and granular activated carbon (GAC) vessels. It recovered free product and treated the contaminated site. Later on, in-situ air sparging of the saturated zone was subsequently added in February 1994. It is reported that GAC had recovered around 118,000 $\mathrm{lbs}$ of free product and reduced the observed apparent thickness of the free product layer to $95 \%$ of the time through December 1993 [81].

\section{Encapsulation}

Encapsulation does not filter contaminants from soil so much as it separates them. One of the most common ways among several methods includes mixing the polluted soil with lime, cement, and concrete leading to preventing the contaminants from spreading to clean soil (Fig. 1). However, this method impedes using the soil for cultivation [82].

In Nigeria two locations of the same climate zone with a mean daily temperature of $280{ }^{\circ} \mathrm{C}$ were selected for investigation named Shell Petroleum Development Company (East) fields located in Agbada and the Port Harcourt Refinery Company located in Alesa-Eleme. The micro-encapsulation process was applied to eliminate the mobility and toxicity of contaminants with aim to reduce the impact of these contaminants on the environment and human health. Considerable reduction in the value of anions such as $\left(\mathrm{SO}_{4}{ }^{2-}, \mathrm{NO}_{3}{ }^{-}\right.$and $\left.\mathrm{PO}_{4}{ }^{3-}\right)$ and metals $(\mathrm{Zn}, \mathrm{Cr}, \mathrm{Ni}, \mathrm{Cd}$, $\mathrm{Cu}$ and $\mathrm{Pb}$ ) has been found $[\mathbf{8 3}]$.

\section{Bioremediation}

This technique is widely accepted among various soil remediation techniques as it involves the treatment with various biological agents [84] (Table 1a). A particular bacterium is targeted at the site to break down hydrocarbons such as petroleum or fuel residues present in the soil [84]. This process comes with a lot of advantage for example when these microbes consume the toxic residues they are killed themselves since the temperature of the soil is nearly $70{ }^{\circ} \mathrm{F}$. During cold climatic conditions soil is properly covered and insulated with microbes [3]. The time taken to completely remediate the contaminated site depends on the prevailing climatic conditions i.e., the colder the climate the longer the clean-up time. Extremophiles, microorganisms with ability to dwell in extreme harsh habitats with robust enzymatic and biocatalytic systems possess the potential for bioremediation of xenobiotic compounds in extreme environments [85] Fig. 1.

Table 1a. Role of different microorganisms in remediation of contaminated sites.

\begin{tabular}{|c|c|c|}
\hline $\begin{array}{l}\text { Microrganisms used } \\
\text { in remediation }\end{array}$ & Remediation of compounds & References \\
\hline $\begin{array}{l}\text { Penicillium } \\
\text { chrysogenum }\end{array}$ & $\begin{array}{l}\text { Hydrocarbons, benzene, } \\
\text { toluene etc. }\end{array}$ & [108] \\
\hline Pseudomonas putida & $\begin{array}{l}\text { Petrol, diesel, polycyclic } \\
\text { aromatic hydrocarbons }\end{array}$ & {$[109,110]$} \\
\hline P.veronii & Polycyclic hydrocarbons & {$[109,110]$} \\
\hline Achromobacter & Diesel & {$[109,110]$} \\
\hline Flavobacterium & $\begin{array}{l}\text { Petrol, diesel, polycyclic } \\
\text { aromatic hydrocarbons. }\end{array}$ & {$[109,110]$} \\
\hline Acenatobacter & Polycyclic hydrocarbons & {$[109,110]$} \\
\hline Pseudomonas putida & Benzene and xylene & {$[76]$} \\
\hline Aspergillus niger & $\begin{array}{l}\text { Hydrocarbon and its } \\
\text { compounds }\end{array}$ & {$[83]$} \\
\hline Cyanobacteria & Naphthalene & {$[111,112]$} \\
\hline Bacillus subtilis & Phenol & [113] \\
\hline Citrobacter & $\mathrm{Ni}$ & [114] \\
\hline $\begin{array}{l}\text { Cyberlindnera } \mathrm{sp} \text {. and } \\
\text { Candida tropicalis }\end{array}$ & $\mathrm{Cr}$ & {$[115,116]$} \\
\hline Neurospora crassa & $\mathrm{Cd}$ & [117] \\
\hline Bacillus subtilis & $\mathrm{Cr}, \mathrm{Cu}, \mathrm{Zn}$ & [118] \\
\hline $\begin{array}{l}\text { Acidithiobacillus } \\
\text { thiooxidans }\end{array}$ & $\mathrm{Cr}, \mathrm{Cu}, \mathrm{Pb}$ and $\mathrm{Zn}$ & [119] \\
\hline $\begin{array}{l}\text { Z-90 strain of } \\
\text { Burkholderia sp. }\end{array}$ & $\mathrm{Mn}, \mathrm{Zn}, \mathrm{Cd}$ & {$[120]$} \\
\hline $\begin{array}{l}\text { Bacillus thuringiensis } \\
\text { OSM29 }\end{array}$ & $\mathrm{Cd}, \mathrm{Cr}, \mathrm{Cu}, \mathrm{Pb}, \mathrm{Ni}$ & {$[121]$} \\
\hline $\begin{array}{l}\text { Verticillium } \\
\text { insectorum }\end{array}$ & $\mathrm{Pb}, \mathrm{Zn}$ & [122] \\
\hline Bacillus cereus & $\mathrm{Mn}$ & [123] \\
\hline $\begin{array}{l}\text { Cupriavidus necator, } \\
\text { Sphingomonas sp. and } \\
\text { Curtobacterium }\end{array}$ & $\mathrm{Cd}$ & {$[124]$} \\
\hline $\begin{array}{l}\text { Macrophomina } \\
\text { phaseolina and } \\
\text { Rhizopus stolonifier }\end{array}$ & $\mathrm{Pb}, \mathrm{Cd}, \mathrm{Cu}, \mathrm{Zn}$ & {$[125]$} \\
\hline
\end{tabular}




\section{Advanced Materials Letters https://aml.iaamonline.org}

Phytoremediation is a method of bioremediation facilitated by the use of plants and considered to be costeffective and less ecologically invasive than conventional civil engineering techniques [86]. Several mechanisms are involved in this technique like phytoextraction, phytostabilization, phytovolatilization, and phytodegradation [87]. This technique has been developed to target both organic contaminants and PTEs [88] and is primarily deployed with the aim to modify and minimize the labile pool of PTEs or degrading organic contaminants. It provides a range of benefits in terms of risk management and low input cost by the selection of certain suitable plants. It also helps in utilisation of remediated sites, carbon sequestration, increased aesthetic value, conservation of the biodiversity, recovery of important metal and metalloids and enhanced production of biomass [89].

\section{Role of biotechnology in soil remediation}

Several microbes such as Clostridium sp. DC-1, KYT-1, Dehalobacter and Nitrosomonas, Pseudomonas have been reported to carry out reductive dichlorination and aerobic degradation of trichloroethylene (TCE), respectively [90]. Biotechnology is used to create transgenic plants and micro-organisms which can serve to degrade toxic soil pollutants. Recombinant microorganisms are effective to remove heavy metals from soil than compared to indigenous microbes [91] (Fig. 1). Through the insertion of genes many recombinant organisms have been designed for removal of chemical pollutants such as n-alkane, aromatic hydrocarbons and polycyclic aromatic hydrocarbons from soil [92]. 1,2,4,5- tetrachlorobenzene and benzene are dehalogenated and dioxygenated by a genetically modified $E$. coli due to the activity of enzymes like TecA chlorobenzene dioxygenase and TodCBA toluene dioxygenase respectively [93].

The spMR68 plasmid a new strain of Pseudomonas is highly resistant to mercuric soil [94]. Many recombinant strains such as E. coli strain M109, P. putida, Deinococcus geothemalis, Cupriavidus metallidurans are employed to remove heavy metals and thus remediate soil (Table 1b). Plants have been engineered by over expression of certain genes such as GSH levels, citrate synthase which make them tolerant towards heavy metals viz., $\mathrm{Cd}, \mathrm{Al}$, etc. [95] (Table 2). Enzymes play a very important role in the biodegradation of pollutants, thus transcription, translation of enzymes when improved helps in better degradation. Through genetic engineering a hybrid cluster of genes is produced, a genetically modified $E$. coli with genes such as toluene metabolic (tod) from $P$. putida F1 and the biphenyl metabolic ( $b p h)$ operon from $P$. pseudoalcaligenes KF707 were found to be faster in degrading TCE than wild type toluene dioxygenase (todC1C2BA) or the original biphenyl dioxygenase genes (bphA1A2A3A4) [96]. Similarly, insertion of genes in Pseudomonas sp. B13 have enabled it to degrade $4 \mathrm{CB}$ or 3,5 -dichlorobenzoate $(3,5 \mathrm{DCB})$ when the inserted gene expressed isofunctional enzyme toluene 1, 2-dioxygenase [97]. Biotechnologically improved plant strains share a distinguished feature of having high biomass and faster growth compared to phytoremediants [98]. Transgenic plants over expressing ATP sulfurylase (APS) showed around two to three times more Se and 1.5 times $\mathrm{S}$ accumulation than wild type plants [99]. Transgenic plants with pesticide toxicity tolerance are developed to effectively remove pesticides from the soil [98] since pesticides toxicity has become an ever-increasing problem in present time owing to its high usage to improve productivity but persist in soil [23]. Transgenic rice plants which together expressed human $C Y P 1 A 1, C Y P 2 B 6$, and $C Y P 2 C 19$ have shown increased tolerance towards several pesticides and better photosynthetic rate and growth in comparison to wild type plants [100], however, many hyperaccumulator species act as extractor of essential nutrients from the soil [101]. This presents a loop requiring future research concerning to systematic application of biotechnology in soil remediation.

Table 1b. Biotechnologically improved strains involved in soil remediation.

\begin{tabular}{|c|c|c|c|}
\hline $\begin{array}{l}\text { Recombinant } \\
\text { microbes/plants }\end{array}$ & $\begin{array}{l}\text { Name of } \\
\text { genes }\end{array}$ & Remediation & Ref. \\
\hline $\begin{array}{l}\text { Eschericia coli } \\
\text { strain M109 } \\
\text { Pseudomonas } \\
\text { putida }\end{array}$ & merA & Hg uptake & {$[126]$} \\
\hline $\begin{array}{l}\text { Deinococcus } \\
\text { geothemalis }\end{array}$ & mer & $\mathrm{Hg}$ & [127] \\
\hline $\begin{array}{l}\text { Pseudomonas } \\
\text { putida } \mathrm{S} 12\end{array}$ & $\begin{array}{l}\text { pheA, pheB, } \\
\text { pheC, pheD, } \\
\text { pheR and } \\
\text { ArsM }\end{array}$ & As removal & $\begin{array}{l}{[128,} \\
129]\end{array}$ \\
\hline $\begin{array}{l}\text { Pseudomonas } \\
\text { putida GPo1, } \\
\text { Rhodococcus } \\
\text { spp., } \\
\text { Rhodococcus } \\
\text { spp. alkB2, } \\
\text { Acinetobacter } \\
\text { spp. alkM }\end{array}$ & $\begin{array}{l}\text { alkB, alkB1, } \\
\text { alkB2, alkM }\end{array}$ & n-alkane degradation & [89] \\
\hline P. putida & $x y l E$ & $\begin{array}{l}\text { Aromatic hydrocarbons } \\
\text { degradation }\end{array}$ & [89] \\
\hline $\begin{array}{l}\text { P. putida, } \\
\text { Mycobacterium } \\
\text { sp. strain PYR-1 }\end{array}$ & $n d o B, \operatorname{nid} A$ & $\begin{array}{l}\text { polycyclic aromatic } \\
\text { hydrocarbons } \\
\text { degradation }\end{array}$ & [89] \\
\hline $\begin{array}{l}\text { Cupriavidus } \\
\text { metallidurans } \\
\text { strain MSR33 }\end{array}$ & $\begin{array}{l}\operatorname{mer} B \text { and } \\
\operatorname{mer} G\end{array}$ & $\mathrm{Hg}$ degradation & [127] \\
\hline $\begin{array}{l}\text { Arabidopsis } \mathrm{sp} . \\
\text { Brassica juncea }\end{array}$ & AtPCS1 & Arsenate, $\mathrm{Cd}$ tolerance & {$[130]$} \\
\hline Tobacco & OsCS1 & Al tolerance & [131] \\
\hline $\begin{array}{l}\text { Pseudomonas } \\
\text { stutzeri } \mathrm{OX} 1\end{array}$ & ToMO & $\begin{array}{l}\text { Tetrachloroethylene de } \\
\text { gradation }\end{array}$ & {$[132]$} \\
\hline $\begin{array}{l}\text { Rhodococcus } \\
\text { strain RHA1 }\end{array}$ & $\begin{array}{l}\text { bphC and } \\
\text { etbC }\end{array}$ & $\begin{array}{l}\text { Biphenyl or } \\
\text { ethylbenzene }\end{array}$ & [133] \\
\hline $\begin{array}{l}\text { Tobacco, } \\
\text { Arabidopsis, and } \\
\text { Alfalfa }\end{array}$ & $a t z A$ & Tolerance to atrazine & [134] \\
\hline Poplar & $\begin{array}{l}\text { mammalian } \\
C Y P 2 B 6 \text { and } \\
\text { PON } 1\end{array}$ & Chlorpyrifos & [95] \\
\hline $\begin{array}{l}\text { Transgenic } \\
\text { tobacco, poplar }\end{array}$ & $\begin{array}{l}\text { mammalian } \\
\text { cytochrome } \\
\text { P450 CYP2E1 }\end{array}$ & Trichloroethanol & $\begin{array}{l}{[135,} \\
136]\end{array}$ \\
\hline
\end{tabular}


Table 2. Application of nanomaterials in soil remediation.

\begin{tabular}{|c|c|c|c|c|}
\hline NPs & Target Pollutant & Major Source & Application & Ref. \\
\hline \multicolumn{5}{|l|}{ Heavy metal remediation } \\
\hline $\begin{array}{l}\text { Nanoscale Zero-valent } \\
\text { Iron (nZVI) }\end{array}$ & $\mathrm{Cr}(\mathrm{VI})$ & $\begin{array}{l}\text { Chemical factories and tannery waste } \\
\text { seeping into soil }\end{array}$ & $\begin{array}{l}\text { Reduction of chromium from } \mathrm{Cr}(\mathrm{VI}) \text { to } \\
\mathrm{Cr} \text { (III) }\end{array}$ & {$[137]$} \\
\hline $\mathrm{nZVI}$ & $\mathrm{As}, \mathrm{Cr}, \mathrm{Pb}, \mathrm{Cd}, \mathrm{Zn}$ & $\begin{array}{l}\text { Lead batteries, pesticides, fertilizers, } \\
\text { coal burning }\end{array}$ & Decline in metal availability & {$[138]$} \\
\hline $\mathrm{Fe}(\mathrm{II})$ phosphate NPs & $\mathrm{Pb}(\mathrm{II})$ & $\begin{array}{l}\text { Paint, pesticide, smoking, automobile, } \\
\text { emission, mining, and burning of coal }\end{array}$ & $\begin{array}{l}\text { Decrease in leachability and bio- } \\
\text { accessibility of soil-bound } \mathrm{Pb}(\mathrm{II}) \text { and } \\
\mathrm{Cu}(\mathrm{II})\end{array}$ & {$[139]$} \\
\hline Nano-Fe/Ca/CaO & As, $\mathrm{Cd}$, and $\mathrm{Pb}$ & Pesticides, fungicides, metal smelters & $\begin{array}{l}\text { Total immobilization of soil heavy metals } \\
\mathrm{As}, \mathrm{Pb} \text {, and } \mathrm{Cd}\end{array}$ & {$[140]$} \\
\hline $\begin{array}{l}\text { Water treatment } \\
\text { residual NPs (nWTR) }\end{array}$ & $\mathrm{Hg}, \mathrm{Cr}$ & Artisanal and Small Scale Mining & $\begin{array}{l}\text { Improved metal sorption for both } \mathrm{Hg} \text { and } \\
\mathrm{Cr} \text { and noteworthy decline in their soil } \\
\text { discharge }\end{array}$ & {$[141]$} \\
\hline \multicolumn{5}{|l|}{ Pesticides remediation } \\
\hline nZVI & DDT & $\begin{array}{l}\text { Organochlorine insecticide, aged } \\
\text { DDT }\end{array}$ & $\begin{array}{l}\text { Whole oxidation and boosted electron } \\
\text { release leading to lessening of pesticide }\end{array}$ & {$[143]$} \\
\hline $\begin{array}{l}\text { Rhenium }(\mathrm{Re}+3)- \\
\text { dopednano- } \mathrm{TiO}_{2}\end{array}$ & Carbofuran & $\begin{array}{l}\text { Toxic carbamate pesticides, systemic } \\
\text { insecticide }\end{array}$ & Photocatalytic deprivation of the pesticide & {$[144]$} \\
\hline $\begin{array}{l}\text { CMC-stabilized nano- } \\
\mathrm{Pd} / \mathrm{Fe}\end{array}$ & $\begin{array}{l}\text { Pentachlorophenol } \\
\text { (PCP) }\end{array}$ & $\begin{array}{l}\text { Pesticide and a disinfectant, } \\
\text { antifouling paint, leather, masonry, } \\
\text { wood preservation }\end{array}$ & De-chlorination to phenol & {$[145]$} \\
\hline $\begin{array}{l}\text { Xanthan gum-- } \\
\text { stabilized nano-Pd/Fe }\end{array}$ & $\begin{array}{l}\text { Polychlorinated } \\
\text { biphenyls (PCBs) }\end{array}$ & $\begin{array}{l}\text { Dielectrics in transformers, coolants, } \\
\text { hydraulic fluids. These seep into the } \\
\text { soil. }\end{array}$ & Solubilization of pesticide & {$[146]$} \\
\hline \multicolumn{5}{|l|}{ Nanophytoremediation } \\
\hline Fe NPs & Cd in wheat & Pesticides, fungicides, metal smelters & $\begin{array}{l}\text { Fall in Cd concentration and hostile } \\
\text { effects, rise in plant growth, } \\
\text { photosynthesis, antioxidant enzymes }\end{array}$ & {$[147]$} \\
\hline $\begin{array}{l}\text { Citrate-coated } \\
\text { magnetite NPs, }\end{array}$ & $\begin{array}{l}\mathrm{Cr}(\mathrm{VI}) \text { in wheat, oat, } \\
\text { sorghum }\end{array}$ & $\begin{array}{l}\text { Chemical factories and tannery waste } \\
\text { seeping into soil }\end{array}$ & Metal toxicity alleviation & {$[148]$} \\
\hline $\mathrm{TiO}_{2} \mathrm{NPs}$ & $\mathrm{Pb}$ in rice & $\begin{array}{l}\text { Paint, pesticide, smoking, automobile, } \\
\text { Lead-acid batteries }\end{array}$ & $\begin{array}{l}\text { Fall in } \mathrm{Pb} \text { bio accumulation in rice tissues } \\
\text { but gathering of NPs in rice roots }\end{array}$ & {$[149]$} \\
\hline Fullerene & $\begin{array}{l}\text { Trichloroethylene in } \\
\text { Cottonwood }\end{array}$ & Industrial solvent & Raised TCE concentration in plant tissues & {$[150]$} \\
\hline MWCNT & $\begin{array}{l}\text { Chlordane and DDE } \\
\text { in Lettuce }\end{array}$ & Pesticide & $\begin{array}{l}\text { The existence of CNT considerably } \\
\text { influenced pesticide availability, } \\
\text { Diminished the root and shoot pesticide } \\
\text { content by } 88 \% \text { and } 78 \% \text {, respectively }\end{array}$ & {$[151]$} \\
\hline $\mathrm{Fe}_{3} \mathrm{O}_{4} \mathrm{NPs}$ & $\begin{array}{l}2,4- \\
\text { Dichlorophenoxyace } \\
\text { ticacid }(2,4-\mathrm{D}) \text { in } \\
\text { Soil indigenous } \\
\text { microbes }\end{array}$ & Pesticides, fungicides & $\begin{array}{l}\text { Higher deterioration efficiency of } \\
\text { herbicide with combined treatment } \\
\text { compared with individual treatments }\end{array}$ & {$[152]$} \\
\hline $\begin{array}{l}\mathrm{Ni} / \mathrm{Fe} \\
\text { bimetallic } \\
\text { nanoparticles }\end{array}$ & $\begin{array}{l}\text { Polybrominated } \\
\text { diphenyl ethers in } \\
\text { Chinese } \\
\text { cabbage }\end{array}$ & $\begin{array}{l}\text { Building materials, flame retardants } \\
\text { and major plastics }\end{array}$ & $\begin{array}{l}\text { Lessening in translocation } \\
\text { of PBDEs }\end{array}$ & {$[153]$} \\
\hline \multicolumn{5}{|c|}{ Nano-enabled sensors in pesticide residue detection } \\
\hline $\begin{array}{l}\text { Au NP-coated Si } \\
\text { nanowires }\end{array}$ & Dichlorvos & Insecticide & $\begin{array}{l}\text { Improved enzymatic activity and } \\
\text { amplified electron communication }\end{array}$ & {$[154]$} \\
\hline $\begin{array}{l}\text { AChE/RGO-Au nano } \\
\text { composite }\end{array}$ & $\begin{array}{l}\text { Organophosphate } \\
\text { and carbamate }\end{array}$ & Insecticide & $\begin{array}{l}\text { Improved electrochemical response due to } \\
\text { electron transfer reaction }\end{array}$ & {$[155]$} \\
\hline $\begin{array}{l}\text { Er-GRO-nafion } \\
\text { nanocomposite }\end{array}$ & Dichlorvos & Insecticide & $\begin{array}{l}\text { High sensitivity, good selectivity, low } \\
\text { detection range }\end{array}$ & {$[156]$} \\
\hline $\begin{array}{l}\text { MWCNT-chitosan } \\
\text { nanocomposites }\end{array}$ & Methyl parathion & Pesticide & $\begin{array}{l}\text { Combined electrochemical reduction of } \\
\text { Ellman's reagent (DTNB) with AChE } \\
\text { inhibition }\end{array}$ & {$[157]$} \\
\hline
\end{tabular}




\section{Advanced Materials Letters https://aml.iaamonline.org}

\section{Nanoremediation}

The expanding use of nanotechnology for ecological cleanup perhaps come from pressing need of an innovation that is cleaner, economical, effectively accessible, and practical while simultaneously faster in conveying results without extra weightage to the cleanup procedure as deposits and environmental persistence $[\mathbf{1 0 2 , 1 0 3}]$. Few nanoparticles (NPs) widely used for soil remediation nowadays are illustrated in Table 2. NPs act as good absorbents [104] since they possess the quality of lower temperature modification, shorter interparticle diffusion distance and variable surface chemistry [105]. All these virtue makes NPs ideal catalysts for chemical reduction and removal of the concerned pollutants. Groundwater circulating well (GCW) technology with engineered nano-materials (ENM) is applied for in-situ treatment of hydrocarbon contaminated waste water [106]. Nanoscale Zero-Valent Iron (NZVI) can remove 1,1,2trichloroethane, effectively does $\mathrm{Cr}$ remediation by reducing $\mathrm{Cr}(\mathrm{VI})$ to $\mathrm{Cr}$ (III) [107]. Hence, these nanomaterials have garnered attention and are considered for soil remediation programs contaminated with pollutants like heavy metals, chlorinated organic solvents, organochlorine pesticides, polycyclic aromatic hydrocarbons (PAHs), and polychlorinated biphenyls (PCBs).

Polymers based NPs are largely used for the detection and removal of heavy metals; $\mathrm{Mn}$, As, nitrate, Fe, gases like $\mathrm{CO}, \mathrm{SO}_{2}, \mathrm{NOx}$, organic pollutants and a wide range of bacteria, viruses and parasites etc. Other NPs such as amphiphilic polyurethane (APU) NPs remediate polynuclear aromatic hydrocarbons (PAHs) from contaminated soils. These NPs have hydrophilic surface which helps in mobility in the soil, whereas the hydrophobic interior renders affinity for the hydrophobic organic contaminants. The APU NPs are known to remove about $80 \%$ phenanthrene from contaminated aquifer sand [108].

The NPs are also widely investigated for their role in degradation of pesticides and POPs. The degradation of pesticide pollutant is caused by photocatalysis. In this method, NPs act as a catalyst in the presence of light and undergoes a series of reaction with pesticides and POPs and converts toxic chemicals into simpler and harmless molecules such as $\mathrm{CO}_{2}, \mathrm{~N}_{2}$ and $\mathrm{H}_{2} \mathrm{O}$. Among various nanophotocatalysts nanoscale $\mathrm{TiO}_{2}$ and $\mathrm{ZnO}$ are designated as good photocatalysts [109] used in contaminated soil.

Nanophytoremediation includes the use of nanotechnology as well as phytotechnology for cleaning soil contaminated with pollutants. Recently many plant species such as tomato, poplar tree, sunflower, willow, chinese cabbage, sunbeam, and alfalfa are tested with positive response for phytoremediation of soils contaminated with pollutant [110]. The most widely studied nanomaterials used in phytoremediation are carbon-based nanomaterials, followed by metal and metal oxide nanomaterials [111]. However, carbon nanotubes are said to be excellent absorbents, due to their large specific surface area [112]. On the other hand fullerenes were found to enhance trichloroethylene (TCE) uptake in cottonwood (Populus eltoides). This showed that the integration of two distinct techniques (nanotechnology with phytoremediation and bioremediation) impacts in two-way i.e., the remediation of harmful pollutants from soil and also promotes growth of the plant. An information whole, however, exists in regard to the utilization of biosynthesized NPs for sustainable environmental applications. Researches are required to outline the possibilities of biosynthesized NPs for the remediation of natural and inorganic contaminations.

\section{Conclusion}

Soil holds an important place in ecosystem as on it are dependent plants, birds, animals and mankind. With advancement in science and technology, the threats to soil have also increased because of disposal of contaminated wastes and depletion of natural resources. The global land is crowded by different kind of industries, major parts are affected by the heavy metals containing industrial effluents which get discharged into water bodies further used in irrigation of crop fields. In order to achieve the food security high application of pesticides resulted in soil pollution due to their persistent behaviour. Ultimately, this soil pollution affects the growth of soil's essential microflora, crop plants and mankind. Thus, several remediation strategies are being used to address the harmful effects of soil pollution on various components of ecosystem. The importance of modern techniques or approaches in improving the ability of microorganisms and plants to degrade or remove pollutants from the soil at a faster rate are emphasized. The study also suggest towards the application of nanoremediation in combination with phyto or bioremediation that not only remediates soil pollution but also improves the plant growth. It is further suggested to execute study in detail as every technique has its side effects.

\section{Acknowledgements}

The authors are very thankful to the Head, Department of Botany, University of Allahabad, for providing essential laboratory facilities. Aparna Pandey is thankful as Junior Research Fellow (UGC-Ref. No.: 627 (CSIR-UGC NET DEC. 2018). Pratibha Singh is grateful to DST for providing post-doctoral fellowship in form of women scientist (WOS b, SoRF). Abreeq Fatima and Divya Gupta are thankful to University Grant Commission, New Delhi for financial support. Professor Sheo Mohan Prasad is thankful to SERB-DST, New Delhi (EMR/2016/004745) for providing financial assistance.

Conflicts of interest

There are no conflicts to declare.

\section{Keywords}

Heavy metals, pesticides, human health, soil fertility, remediation.

Received: 5 May 2021

Revised: 27 June 2021

Accepted: 15 July 2021 


\section{Advanced Materials Letters https://aml.iaamonline.org}

\section{References}

1. Trivedi, V.K.; Acta. Sci. Agric., 2018, 2, 50.

2. Jacoby, R.; Peukert, M.; Succurro, A.; Koprivova, A.; Kopriva, S.; Front. Plant Sci., 2017, 8, 1

3. Baveye, P.C.; Otten, W.; Kravchenko, A.; Balseiro-Romero, M.; Beckers, E.; Chalhoub, M.; Darnault, C.; Eickhorst, T.; Garnier, P.; Hapca, S.; Kirnayaz, S.; Monga, O.; Mueller, C.W.; Nunan, N.; Pot, V.; Schluter, S.; Schmidy, H.; Vogel, H.; Front. Microb., 2018, 9, 1929.

4. Dominati, E.; Patterson, M.; Mackay, A.; Ecol. Econ., 2010, 69, 858.

5. Raynaud, X.; Nunan, N.; PLoS One, 2014, 9, e87217.

6. Zaccardelli, M.; De, N.F.; Villecco, D.; Scotti, R.; J. Plant Nutr. Soil Sci., 2013, 13.

7. Rodríguez-Eugenio, N.; McLaughlin, M.; Pennock, D.; FAO, 2018, 142.

8. Singh, P.; Prasad, S.M.; Sci. Total Environ., 2018, 630, 839.

9. FAO. Food and Agriculture Organization of United Nations, World Symposium on soil pollution. 2018. FAO, Rome-Italy.

10. Mishra, R.K.; Roychoudhury, N.; Mohammad, N.; VAN SANGYAN, 2016, 3, 1 .

11. Singh, P.; Prasad, S.M.; Plant Arch., 2019, 19, 496.

12. Jaramillo, M.F.; Restrepo, I.; Sustainability, 2017, 9, 1.

13. Duarte, A.C.; Cachada, A.; Rocha-Santos, T.; Academic Press, an imprint of Elsevier, 2018.

14. Ashraf, M.A.; Maah, M.J.; Yusoff, I.; Intech Open. 2014, http://doi/10.5772/57287.

15. Aleksakhin, R.M.; Eurasian Soil Sci., 2009, 42, 1386.

16. Hussain, R.; Luo, K.; Chao, Z.; Zhao, X.; Environ. Sci. Pollut. Res., 2018, 25, 19566

17. Albanese, S.; De Vivo, B.; Lima, A.; Cicchella, D.; J. Geochem. Explor., 2007, 93, 21.

18. Sun, F.; Ma, Y.; Guo, H.; Ji, R. Fate of Several Typical Organic Pollutants in Soil and Impacts of Earthworms and Plants, In Twenty Years of Research and Development on Soil Pollution and Remediation in China, Singapore; Luo, Y.; Tu, C. (Eds.); Springer: Singapore, 2018, pp.575-589.

19. Kinuthia, G.K.; Ngure, V.; Beti, D.; Lugalia, R.; Wangila, A.; Kamau, L.; Sci. Rep., 2020, 10, 8434.

20. Kacprzak, M.; Neczaj, E.; Fijałkowski, K.; Grobelak, A.; Grosser, A.; Worwag, M.; Rorat, A.; Brattebo, H.; Almas, A.; Singh, B.R.; Environ. Res., 2017, 156, 39.

21. CEU (Council of the European Union) 1999. Council Directive 1999/ 31/ EC of 26th April, 1999 on the landfill of waste. http://www.eugris.info/displayresource.aspx?r=5795

22. Sharma, R.K.; Agrawal, M.; Marshall, F.; Ecotoxicol Environ. Saf., 2007, 66, 258 .

23. Srivastava, P.K.; Singh, V.P.; Singh, A.; Tripathi, D.K.; Singh, S.; Prasad S.M.; Chauhan, D.K. (Eds.); Pesticides in Crop Production: Physiological and Biochemical Action; John Wiley \& Sons Ltd., 2019.

24. Fernandes, C.L.F.; Volcão, L.M.; Ramires, P.F.; Moura, R.; Da Silva Junior, F.M.R.; Environ. Sci. Process. Impacts, 2020, 22, 256.

25. Silva, V.; Montanarella, L.; Jones, A.; Fernandez-Ugalde, O.; Mol, H.G.J.; Ritsema, C.J.; Geissen, V.; Sci. Total Environ., 2018, 621, 1352.

26. Abhilash, P.C.; Singh, N.; J. Haz Mat., 2009, 165, 1.

27. Sharma, A.; Kumar, V.; Thukral, A.K.; Bhardwaj, R.; Planta Daninha, 2019, 37.

28. Reikard, G.; Atmos Environ., 2019, 1, 100001.

29. United States Geological Survey 2009. Volcanic air pollution, Kilauea Volcano, Hawai'i. http://volcanoes.usgs.gov/hazards/gas/ volgspollution.php.

30. Viscardi, M.H.; da Silveira, L.F.; Vargas, L.K.; da Silva, R.F.; Beneduzi, A.; Water Air Soil Pollut., 2020, 231, 318.

31. Grennfelt, P.; Engleryd, A.; Forsius, M.; Øystein, H.; Henning, R.; Cowling, E.; J. Environ. Sci., 2020, 49, 849-864.

32. Kaupenjohann, M.; Nätscher, L.; Schwertmann, U.; Süsser, P.; Schwertmann, U.; Horn, R.; Taubner, H.; Hantschel, R.; Kaupenjohann, M.; Zech, W.; Schneider, B. Effects of Acid Rain on Soil Chemistry and Nutrient Availability in the Soil, In Handbook of
Forest Decline and Air Pollution Ecological Studies (Analysis and Synthesis); Schulze, ED.; Lange, OL.; Oren, R. (Eds.); Springer: Berlin, Heidelberg, 1989, pp.7.

33. Popp, J.; Peto, K.; Nagy, J.; Agro. Sustain. Develop., 2013, 33, 243.

34. Shahbaz, M.; Ashraf, M.; Crit. Rev. Plant Sci., 2013, 32, 237.

35. Singh, S.; Prasad, S.M.; Singh, V.P.; J. Hazar. Mat., 2020, 398, 122607

36. Bradford, A.; 2018, Livescience.com

37. Singh, R.; Parihar, P.; Prasad, S.M.; Sci. Rep., 2020, 10, 6900.

38. Bashri, G.; Prasad, S.M.; Ecotox. Environ. Saf., 2016, 132, 329.

39. Debnath, B.; Ahammed, G.J.; Effect of acid rain on plant growth and development. In Handbook of Physiological and molecular interventions Contaminants in Agriculture, Naeem, M., Ansari, A., Gill, S. (Eds.); Springer, Cham. 2020.

40. FAO 2015. ITPS (Food and Agriculture Organization of the United Nations and Intergovernmental Technical Panel on Soils), Status of the World's Soil Resources (SWSR), Rome, Italy.

41. Singh, P.; Ghoshal, N.; Ecos. Environ., 2010, 137, 241.

42. Poffenbarger, H.J.; Barker, D.W.; Helmers, M.J.; Miguez, F.E.; Olk, D.C.; Sawyer, J.C.; Six, J.; Castellano, M.J.; PLOS One, 2017, 12, e0172293.

43. Jaishankar, M.; Tseten, T.; Anbalagan, N.; Mathew, B.B.; Beeregowda, K.N.; Interdiscip. Toxicol., 2014, 7, 60.

44. Meena, R.S.; Kumar, S.; Datta, R.; Lal, R.; Vijayakumar, V.; Brtnicky, M.; Sharma, M.P.; Yadav, G.S.; Jhariya, M.K.; Jangir, C.K.; Pathan, S.I.; Dokulilova, T.; Pecina, V.; Marfo, T.D.; Land, 2020, 9, 34

45. Singh, P.; Ghoshal, N.; Singh, R.P.; Soil Sci. Soc. Am J., 2011, 76, 2208.

46. Singh, S.; Mishra, R.; Singh, A.; Ghoshal, N.; Singh K.P.; Soil Sci. Soc. Am J., 2009, 5, 1530.

47. Patel, A.; Tiwari, S.; Prasad S.M.; Ecotoxicol. Environ. Saf., 2018 157, 369 .

48. Tiwari, S.; Patel, A.; Prasad, S.M.; BMC Microb., 2020, 20, 206.

49. Tiwari, S.; Verma, N.; Prasad, S.M.; Singh V.P.; Chemosphere, 2020, 259, 127356

50. Shegunova, P.; Teruze, K.; Atanasov, I.; Priority organic pollutants in soils of Bulgaria. In Assessment of the quality of contaminated soil and sites in Central and Eastern European Countries (CEEC) and New Independent States. Int. Workshop. 3, Sofia, Bulgaria. Proceedings, 2001, pp.202-208.

51. Dusek, L.; Plant Soil, 1995, 176, 273.

52. McGrath, S.P.; Chaudri, A.M.; Giller, K.E.; J. Ind. Microb. Biotechnol., 1995, 14, 94

53. Aqeel, M.; Jamil, M.; Yusoff, I.; 2014. http://doi/10.5772/57287.

54. Endo, T.; Hisamichi, Y.; Haraguchi, K.; Kato, Y.; Ohta, C.; Koga, N.; Mar. Pollut. Bull., 2008, 56, 1774 .

55. Pethybridge, H.; Cossa, D.; Butler, E.C.V.; Mar. Environ. Res., 2010, 69, 18.

56. Bech, J.; Environ. Geochem. Hlth., 2020, 42, 1.

57. Sasakova, N.; Gregova, G.; Takacova, D.; Mojzisova, J.; Papajova, I.; Venglovsky, J.; Szaboova, T.; Kovacova, S.; Front. Sustain. Food Syst., 2018, 2, 42 .

58. Hasan, M.K.; Shahriar, A.; Jim, K.U.; Heliyon, 2019, 5, e02145.

59. Bellanger, M.; Pichery, C.; Aerts, D.; Berglund, M.; Castano, A.; Environ. Hlth., 2013, 12, 3 .

60. Tong, S.; von Schirnding, Y.E.; Prapamontol, T.; Bulletin of the World Health Organisation, 2000, 78, 1068.

61. Rana, M.N.; Tangpong, J.; Rahman, M.M.; Toxicol. Rep., 2018, 5, 704.

62. Jadiyappa, S.; Radioisotope: Applications, Effects, and Occupational Protection, Principles and Applications. In Nuclear Engineering - Radiation Effects, Thermal Hydraulics, Radionuclide Migration in the Environment, Rahman, R. O. A.; El-Din, H., Saleh, M. (Eds.); IntechOpen, 2018, https://doi.org/10.5772/intechopen.79161.

63. Bai, H.; Hu, B.; Wang, C.; Bao, S.; Sai, G.; Xu, X.; Zhang, S.; Li, Y.; Int. J. Env. Res. Pub. He., 2017, 14, 300.

64. Zverev, V.E., Russ. J. Ecol., 2009, 40, 254.

65. Eeva, T.; Lehikoinen, E.; Funct. Ecol., 2004, 18, 548.

66. Menta, C.; 2012. https://doi.org/10.5772/51091. 


\section{Advanced \\ Materials Letters \\ https://aml.iaamonline.org}

67. Dutta, H.; Energy Ecol. Environ., 2017, 2, 329.

68. Parihar, M.; 2019. Mass bird deaths at Sambhar Lake point to problem within. indiatoday.in

69. Eeva, T.; Belskii, E.; Gilyazov, A.S.; Kozlov, M.Z.; Biol. Conser., 2012, 150, 33 .

70. Mitra, A.; Chatterjee, C.; Mndal, F.B.; Res J. Environ. Toxicol., 2011, 5,81 .

71. Mnif, W.; Hassine, A.I.H.; Bouaziz, A.; Bartegi, A.; Thomas, O.; Roig, B.; Inter. J. Environ. Res. Pub. Hlth., 2011, 8, 2265.

72. Ccanccapa, A.; Masiá, A.; Navarro-Ortega, A.; Picó, Y.; and Barceló, D.; Environ. Pollu., 2016, 211, 414.

73. United Nations Environment Programme (UNEP). 2018. World Migratory Bird Day: birds globally threatened by plastics waste. Ecosystems and biodiversity. unenvironment.org

74. WWF. 2018. How many birds die from plastic pollution? wwf.org.au

75. Parker, L.; 2019. The world's plastic pollution crisis explained. Nationalgeographic.com

76. Cai, C.; Zhao, M.; Yu, Z.; Rong, H.; Zhang, C.; The Sci Tot Environ., 2019, 662, 205.

77. Bahadure, S.; Kalia, R.; Chavan, R.; IJBBR, 4, 677.

78. Vidonish, J.E.; Zygourakis, K.; Masiello, C.; Sabadell, G.; Alvarez, P.J.J.; 2016. https://doi.org/10.1016/J.ENG.2016.04.005

79. Speight, J.G.; Chem. Technol., 2020, Butterworth-Heinemann, 263.

80. Bass, D.H.; Hastings, N.A.; Brown, R.A.; J. Hazar. Mat., 2000, 72, 101

81. National Service Center for Environmental Publications (NSCEP). 1995. Federal Remediation Technologies Roundtable: Five Years of Cooperation. EPA 542/F-95/007.

82. Rada, E.C.; Andreottola, G.; Istrate, I.A.; Viotti, P.; Conti, F.; Magaril, E.R.; IJBBR, 2019, 16, 3179.

83. Wami, N.E.; Nmegbu, C.G.J.; Int. J. Eng. Res., 2015, 6, 815

84. Hassan, I.; Ai-Jawhari, H.; Degradation of Pollutants Using Advanced Ecomaterials, 2019, 21.

85. Shukla, A.K.; Singh, A.K.; Curr. Genom., 2020, 21, 161

86. Ashraf, S.; Ali, Q.; Zahir, Z.A.; Ashraf, S.; Asghar, H.A.; Ecotoxicol. Environ. Saf., 2019, 174, 714.

87. Ali, H.; Khan, E.; Sajad, M.A.; Chemosphere, 2013, 91, 869

88. Ifon, B.E.; Togbé, A.C.F.; Tometin, L.A.S.; Suanon, F.; Yessoufou, A.; 2019. DOI: 10.5772/intechopen. 81223 .

89. Pandey, V.C.; Bajpai, O.; 2019. https://doi.org/10.1016/B978-0-12813912-7.00001.6.

90. Shukla, A.K.; Upadhyay, S.N.; Dubey, S.K.; Crit. Rev. In. Biotechnol., 2012, 34(2), 101

91. Azad, M.A.K.; Amin, L.; Sidik, N.M.; Science Bulletin, 2014, 59, 703.

92. Wolejko, E.; Wydro, U.; Loboda, T.; Ecol. Chem. Eng. S, 2016, 23, 155.

93. Beil, S.; Mason, J.R.; Timmis, K.N.; Pieper, D.H.; J. Bacteriol., 1998, 180,5520

94. Sone, Y.; Mochizuki, Y.; Koizawa, K.; Pan, Hou-H.; Itoh, T.; Kiyono, M.; AMB Express, 2013, 3, 41.

95. Gunarathne, V.; Mayakaduwa, S.; Ashiq, A.; Weerakoon, S.; Biswas, J.; Vithanage, M. Transgenic Plants: Benefits, Applications, and Potential Risks in Phytoremediation. In Transgenic Plant Technology for Remediation of Toxic Metals and Metalloids, Academic Press. 2019, pp.89-102

96. Furukawa, K.; Hirose, J.; Hayashida, S.; Nakamura, K.; J. Bacteriol., 1994, 176, 2121

97. Reineke, W.; Knackmuss, H.J.; J. Bacteriol., 1980, 142, 467.

98. Buhari, M.L.; Sulaiman, B.R.; Vyas, N.L.; Sulaiman, B.; Harisu, U.Y.; J. Bioremed Biodeg., 2016, 7, 330.

99. Pilon-Smits, E.A.; Hwang, S.; Mel, L.C.; Zhu, Y.; Tai, J. C.; Bravo, R. C.; Chen, Y.; Leustek, T.; Terry, N.; Plant Physiol.; 1999, 119, 123.

100. Kawahigashi, H.; Hirose, S.; Ohkawa, H.; Ohkawa, Y.; J. Agric. Food Chem., 2006, 54, 2985.

101. Ghosh, M.; Singh, S. A.; J. Eng. Educ., 2005, 6, 18.

102. Yan, W.; Lien, H.L.; Koel, B.E.; Zhang, W.X.; Environ. Sci. Process Imp., 2013, 15, 63

103. Cai, C.; Zhao, M.; Yu, Z.; Rong, H.; Zhang, C.; Sci. Total Environ., 2019, 662, 205.

104. Gong, X.; Huang, D.; Liu, Y.; Peng, Z.; Zeng, G.; Xu, P.; Cheng, M.; Wang, R.; Wan, J.; Cri. Rev. Biotechnol., 2018, 38, 455.
105. Tang, W.W.; Zeng, G.M.; Gong, J.L.; Liang, J.; Xu, P.; Zhang, C. Huang, B.B.; Sci. Total Environ., 2014, 468, 1014.

106. Zhang, T.; Lowry, G.V.; Capiro, N.L.; Chen, J.; Chen, W.; et. al., Environ. Sci.: Nano, 2019, 6, 1283.

107. Gheju, M.; Water. Air. Soil. Poll., 2011, 222, 103.

108. Peikam, E.N.; Jalali, M.; Int. J. Environ. Sci. Technol., 2018, 1.

109. Fujishima, A.; Zhang, X.; Tryk, D.A.; Surf. Sci. Rep., 2008, 63, 515

110. Mitton, F.M.; Miglioranza, K.S.; Gonzalez, M.; Shimabukuro, V.M.; Monserrat, J.M.; Ecol. Eng., 2014, 71, 501

111. Chen, M.; Zeng, G.; Xu, P.; Zhang, Y.; Jiang, D.; Zhou, S.; Environ Sci. Nano., 2017, 4, 720 .

112. Song, B.; Xu, P.; Chen, M.; Tang, W.; Zeng, G.; Gong, J.; Zhang, P.; Ye, S.; Cri. Rev. Environ. Sci. Technol., 2019, 49, 791.

113. Pereira, P.; Enguita, F.J.; Ferreira, J.; Leitão, A.L.; Toxicol. Rep., 2014, 4, 1096

114. Safiyanu, I.; Abdulwahid, I.A.; Abubakar, U.S.; Rita, S.M.; RJPBCS, 6, 783.

115. Sani, I.; Safiyanu, I.; Rita, S.M.; Int. J. Environ. Sci. Technol. Res. $\mathbf{2 0 1 5}, 3,41$

116. Lin, W.; Lin, M.; Zhou, H.; Wu, H.; Li, Z.; Lin, W.; PLoS One, 2019 14, e 0217018

117. Sivakumar, G.; Xu, J.; Thompson, R.W.; Yang, Y.; Randol-Smith, P.; Weathers, P.J.; Bio. Tech., 2012, 107, 1.

118. Singh, A.; Kumar, V.; Srivastava, J.N.; J. Pet. Environ. Biotechnol. 2013, 4,1

119. Ma, Y.; Li, X.; Mao, H.; Wang, B.; Chem. Eng. J., 2018, 353, 410.

120. Bahafid, W.; Joutey, N.T.; Sayel, H.; Boularab, I.; Ghachtouli, N.; EL.; J. App. Microbiol., 2013, 11, 727.

121. Bahafid, W.; Joutey, N.T.; Sayel, H.; Asri, M.; Laachari, F. J.; Mat. Environ. Sci., 2017, 8, 438

122. Li, Q.; Csetenyi, L.; Gadd, G.M.; Environ. Sci. Technol., 2014, 48 , 14409.

123. Maity, J.P.; Chen, G.S.; Huang, Y.H.; Ao, Y.; Geomicrobiol. J., 2019, 1.

124. Wen, Y.M.; Wang, Q.P.; Tang, C.; Chen, Z.; J. Soils Sed., 2012, 12 900.

125. Yang, Z.; Zhang, Z.; Chai, L.; Wang, Y.; Liu, Y.; Xiao, R.; J. Haz Mat., 2016, 301, 145 .

126. Oves, M.; Khan, M.S.; Zaidi, A.S.; J. Biol. Sci., 2013, 20, 121-129.

127. Feng, C.L.; Li, J.; Li, X.; Li, K.; Luo, K.; Liao, X.; Liu, T.; PLOS One, 2018, 13, e0203859.

128. Zhenggang, X.; Yi, D.; Huimin, H.; Liang, W.; Yunlin, Z.; Guiyan, Y.; Pol. J. Environ. Stud., 2018, 28, 463.

129. Li, X.; Li, D.; Yan, Z.; and Ao, Y.; R. Soc. Chem., 2018, 8, 30902.

130. Fawzy, E.M.; Abdel-Motaal, F.F.; El-zayat, S.A.; J. Toxicol. Environ. Hlth. Sci., 2017, 9, 35.

131. Yadav, M.; Shukla, A, K.; Srivastava, N.; Upadhyay, S.N.; Dubey, S.; Critic. Rev. Biotechnol., 2015, 36(4), 1.

132. Deckwer, W.D.; Becker, F.; Ledakowicz, S.; Wagner-Döbler, I.; Environ. Sci. Technol., 2004, 38, 1858

133. Dixit, R.; Malaviya, D.; Pandiyan, K.; Singh, U.B.; Sahu, A.; Shukla R.; Singh, B.P.; Rai, J.P.; Sharma, P.K.; Lade, H.; Paul, D.; Sustain., $\mathbf{2 0 1 5}, 7,2189$

134. Marconi, A.M.; Kieboom, J.; de Bont, J.A.; Biotechnol. Let., 1997, 19, 603.

135. Liu, S.; Zhang, F.; Chen, J.; Sun, G.; J. Environ. Sci., 2011, 23, 1544.

136. Gasic, K.; Korban, S.S.; Plant Mol. Biol., 2007, 64, 361.

137. Han, Y.; Zhang, W.; Zhang, B.; Zhang, S.; Wang, W.; Ming, F.; Mol. Biotechnol., 2009, 42, 299.

138. Ryoo, D.; Shim, H.; Canada, K.; Barbieri, P.; Wood, T.K.; Nat. Biotechnol., 2000, 18, 775.

139. Hauschild, J.E.; Masai, E.; Sugiyama, K.; Hatta, T.; Kimbara, K. Fukuda, M.; Yano, K.; Appl Environ. Microbiol., 1996, 62, 2940.

140. Heaton, A.C.P.; Rugh, C.L.; Wang, N.J.; Meagher, R.B.; Water Air Soil Pol., 2005, 161, 137

141. Doty, S.L.; James, C.A.; Moore, A.L.; Vajzovic, A.; Singleton, G.L.; Ma, C.; Khan, Z.; Xin, G.; Kang, J.W.; Park, J.Y.; Meilan, R.; Strauss, S.H.; Wilkerson, J.; Farin, F.; Strand, S.E.; Proceedings of the National Academy of Sciences of the United States of America 2007, 104, 16816 
142. Doty, S. L.; Shang, T. Q.; Wilson, A. M.; Tangen, J.; Westergreen, A. D.; Newman, L. A.; Strand, S. E.; Gordon, M. P.; Procd Natl Acad. Sci USA, 2000, 97, 6287.

143. Singh, R.; Misra, V.; Singh, R.P.; Bull. Environ. Contam. Toxicol., 2012, 88, 210.

144. Saccà, M.L.; Fajardo, C.; Martinez-Gomariz, M.; Costa, G.; Nande, M.; Martin, M.; Water, Air Soil Pol., 2014, 225, 1990.

145. Liu, R.; Zhao, D.; Chemosphere, 2013, 91, 594.

146. Mallampati, S.R.; Mitoma, Y.; Okuda, T.; Sakita, S.; Kakeda, M.; Environ. Chem. Let., 2013, 11, 119.

147. Moharem, M.; Elkhatib, E.; Mesalem, M.; Environ. Res., 2019, 170, 366.

148. Restivo, J.; Orfao, J.J.M.; Armenise, S.; Garcia-Bordej_e, E.; Pereira, M.F.R.; J. Haz. Mat., 2012, 239, 249

149. El-Temsah, Y.S.; Sevcu, A.; Bobcikova, K.; Cernik, M.; Joner, E.J.; Chemosphere, 2016, 144, 2221.

150. Rui, Z.; Jingguo, W.; Jianyu, C.; Lin, H.; Kangguo, M.; J. Rare Earths., 2010, 28, 353.

151. Yuan, S.; Long, H.; Xie, W.; Liao, P.; Tong, M.; Geoderma, 2012, $185,18$.

152. Lo' pez-Luna, J.; Silva-Silva, M.J.; Martinez-Vargas, S.; MijangosRicardez, O.F.; Gonzalez-Chavez, M.C.; Solís-Domínguez, F.A.; Cuevas-Díaz, M.C.; Sci. Total Environ., 2016, 565, 941.

153. Cai, F.; Wu, X.; Zhang, H.; Shen, X.; Zhang, M.; Chen, W.X.; Gao, Q.; White, J.C.; Tao, S.; Wang, X.L.; Nano Impact, 2017, 5, 101.

154. Ma, X.; Wang, C.; Environ. Eng. Sci., 2010, 27, 989.

155. Hamdi, H.; Torre-Roche, R.D.L.; Hawthorne, J.; White, J.C.; Nanotoxicol., 2015, 9, 172.

156. Fang, G.; Si, Y.; Tian, C.; Zhang, G.; Zhou, D.; Environ. Sci. Pol. Res., 2012, 19, 784.

157. Wu, J.; Xie, Y.; Fang, Z.; Cheng, W.; Tsang, P.E.; Chemosphere, 2016, 162, 235.

158. Su, S.; He, Y.; Zhang, M.; Yang, K.; Song, S.; Zhang, X.; Fan, C.; Lee, S.; Appl. Phy. Let., 2008, 93, 023113.

159. Liu, T.; Su, H.; Qu, X.; Ju, P.; Cui, L.; Ai, S.; Sens. Actuators B. Chem., 2011, 160, 1255.

160. Wu, S.; Huang, F.; Lan, X.; Wang, X.; Wang, J.; Meng, C.; Sens. Actuators B. Chem., 2013, 177, 724.

161. Dong, J.; Fan, X.; Qiao, F.; Ai, S.; Xin, H.; Anal. Chim. Acta., 2013, 761, 78.

162. Fan, G.; Cang, L.; Qin, W.; Zhou, C.; Gomes, H.I.; Zhou, D.; Sep. Purif. Technol., 2013, 114, 64.

163. Hussain, A.; Ali, S.; Rizwan, M.; Qayyum, M.F.; Wang, H.; Rinklebe J.; Ecotoxicol. Environ. Saf., 2019, 173, 156.

\section{Graphical abstract}

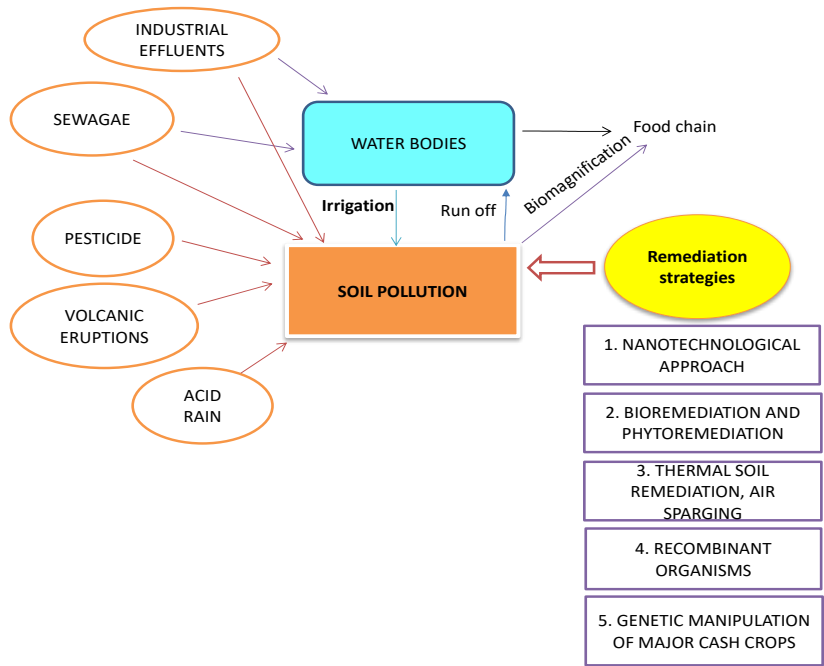

\section{Authors biography}

Aparna Pandey is working as a Ph.D. student under supervision of Prof. Sheo Mohan Prasad in the department of botany, University of Allahabad. She is a junior research fellow (CSIR- UGC-JRF (Ref. No. 627 CSIRUGC-NET Dec. 2018) along with GATE and JGEEBILS. She has published 1 research paper and 2 review articles with few chapters and reviews communicated. She has also received "Swarnajayanti puraskar" for best oral presentation in $89^{\text {th }}$ Annual Session of NASI.

Pratibha Singh has worked as DST-Women Scientist b (WOS b) in the Department of Botany at the University of Allahabad, India. Her areas of expertise include sustainable agriculture and the side effects of abiotic stresses present in the environment on soil and plants. The research work aims towards a holistic approach to achieving sustained soil fertility and productivity along with maintenance of plant health in terms of physiology and biochemistry in tropical croplands. Dr. Singh obtained her PhD in Botany from Banaras Hindu University, Varanasi, India. She received several fellowships from UGC, CSIR, and DST during her doctoral and postdoctoral programs. She has authored several scientific publications, two textbooks and one edited book with reputed international publishers. She bagged several prizes as young scientist and on the best oral presentation award in an international conference. She has also delivered an invited talk at Malaya University, Kuala Lumpur, Malaysia. Dr. Singh is also the life member of Blue Planet Society and the Society for Science and Nature.

Divya Gupta has done her post-graduation in Botany from University of Allahabad. Then after she has cleared CSIR- NET. She joined Ph.D. in subject Plant Physiology in Ranjan Plant Physiology and Biochemistry Laboratory, University of Allahabad. Recently she has submitted her thesis. Till now she has 4 research papers and 3 chapters. She was also awarded first prize for "Best oral presentation" in a National seminar organized by Allahabad Chapter Indian Science Congress Association.

Abreeq Fatima did post-graduation in Botany from University of Allahabad. Joined Ph.D. in subject Plant Physiology in Ranjan Plant Physiology and Biochemistry Laboratory, University of Allahabad. Till now she has published 9 articles. She was also awarded first prize for "Best oral presentation" in a National seminar organized by Allahabad Chapter Indian Science Congress Association, India.

Prof. Sheo Mohan Prasad is a professor of Physiology and Biochemistry in Department of Botanty, University of Allahabad with his research specialization in the area of oxidative stress, anti-oxidant system and signaling in plants and cyanobacteria in abiotic stressed conditions. He is Fellow of National Academy of Sciences. He has awarded $30 \mathrm{Ph} . \mathrm{D}$ degrees along with 8 current working members and 4 post doctoral fellows. His publications currently have total 8147 citations and 578.6 impact factor. 